\title{
Efficacy of Bacterial Adaptation on Copper Biodissolution from a Low Grade Chalcopyrite Ore by A. ferrooxidans
}

\author{
Abhilash", Kapil Deo Mehta, Bansi Dhar Pandey \\ CSIR-National Metallurgical Laboratory, Jamshedpur, India \\ Email: ${ }^{*}$ biometnml@gmail.com
}

Received March 5, 2012; revised April 6, 2012; accepted April 16, 2012

\begin{abstract}
A low-grade ore containing $\sim 0.3 \% \mathrm{Cu}$, remains unutilized for want of a viable process at Malanjkhand Copper Project (MCP), India in which copper is present as chalcopyrite associated with pyrite in quartz veins and granitic rocks. In order to extract copper from this material, bioleaching has been attempted on bench scale using Acidithiobacillus ferrooxidans (A. ferrooxidans) isolated from the native mine water. The enriched culture containing A. ferrooxidans when adapted to the ore and employed for the bioleaching at $5 \%(\mathrm{w} / \mathrm{v})$ pulp density, $\mathrm{pH} 2.0$ and $25^{\circ} \mathrm{C}$ with three particle sizes viz. $150-76 \mu \mathrm{m}, 76-50 \mu \mathrm{m}$ and $<50 \mu \mathrm{m}$, resulted in recovery of $38.31 \%, 29.68 \%$ and $47.5 \% \mathrm{Cu}$ respectively with a maximum rise in redox potential $\left(\mathrm{E}_{\mathrm{SCE}}\right)$ from 530 to $654 \mathrm{mV}$ in 35 days. Under similar conditions, the unadapted strains gave a recovery of $44.0 \%$ for $<50 \mu \mathrm{m}$ size particles with a rise in $\mathrm{E}_{\mathrm{SCE}}$ from 525 to $650 \mathrm{mV}$. On using unadapted bacterial culture directly in shake flask at $\mathrm{pH} 2.0$ and $35^{\circ} \mathrm{C}$ temperature and $5 \%(\mathrm{w} / \mathrm{v})$ pulp density $(\mathrm{PD})$ for $<50 \mu \mathrm{m}$ size particles, $72 \% \mathrm{Cu}$ bio-dissolution was achieved in 35 days. Copper biorecovery increased to $75.3 \%$ under similar conditions with a rise in bacterial count from $1 \times 10^{7}$ cells $/ \mathrm{mL}$ to $1.13 \times 10^{9}$ cells $/ \mathrm{mL}$ in 35 days. The higher bio-recovery of copper with the adapted bacterial culture may be attributed to the improved iron oxidation $\left(\mathrm{Fe}^{2+}\right.$ to $\left.\mathrm{Fe}^{3+}\right)$ exhibiting higher $\mathrm{E}_{\mathrm{SCE}}$ as compared to that of unadapted strains.
\end{abstract}

Keywords: Bioleaching; Low-Grade Ore; Chalcopyrite; Acidithiobacillus ferrooxidans

\section{Introduction}

With the depletion of high grade resources of ores, there is a need to process low grade/discarded ores and tailings to meet the current demand of metals. The existing conventional processes are not suitable to recover the metals from such resources due to high energy consumption and environmental pollution. Biohydrometallurgy is one such approach which is environmentally benign and can be used to recover metals economically with the application of microbes [1]. The understanding of bio-leaching process began with the isolation of a mesophilic and acidophilic bacteria from mine waters by Colmer and Hinke (1947) and its usage in bioleaching of copper ores [2]. The bacteria such as Acidithiobacillus ferrooxidans (A. ferrooxidans) have been often used for dissolution of copper from different low grade ores and tailings [3-5]. Various researchers have been actively involved in elucidating the role of bacteria in bioleaching while catalyzing the oxidation of metal sulfides [6-11]. Two mechanisms of bacterial action for sulfide oxidation with A. ferrooxidans have been suggested: 1) direct mechanism involving

${ }^{*}$ Corresponding author. bacterial oxidation through enzymatic reaction, and 2) indirect mechanism, where the bacteria generate Fe(III) by the oxidation of $\mathrm{Fe}(\mathrm{II})$, which in turn oxidizes the metal sulfides [10].

The bioleaching of copper from a low grade chalcopyrite ore is reported to involve both direct and indirect leaching mechanism [11]. The direct mechanism proceeds through the attachment of A. ferrooxidans (Ac. Tf) on the surface of minerals viz., $\mathrm{CuFeS}_{2}$ and $\mathrm{FeS}_{2}$ (pyrite) to oxidize the metals.

$$
\begin{gathered}
\mathrm{CuFeS}_{2}+\mathrm{O}_{2}+2 \mathrm{H}_{2} \mathrm{SO}_{4} \stackrel{\text { Ac.Tf }}{\rightarrow} \mathrm{CuSO}_{4}+\mathrm{FeSO}_{4}+2 \mathrm{~S}+2 \mathrm{H}_{2} \mathrm{O} \\
2 \mathrm{FeSO}_{4}+\mathrm{H}_{2} \mathrm{SO}_{4}+1 / 2 \mathrm{O}_{2} \stackrel{\text { Ac.Tf }}{\rightarrow} \mathrm{Fe}_{2}\left(\mathrm{SO}_{4}\right)_{3}+\mathrm{H}_{2} \mathrm{O} \\
2 \mathrm{FeS}_{2}+2 \mathrm{H}_{2} \mathrm{SO}_{4}+\mathrm{O}_{2} \stackrel{\text { Ac.Tf }}{\rightarrow} 2 \mathrm{FeSO}_{4}+2 \mathrm{H}_{2} \mathrm{O}+4 \mathrm{~S}^{\mathrm{O}}
\end{gathered}
$$

The dissolution of chalcopyrite also involves oxidative ferric reaction with the mineral, which essentially represents indirect leaching mechanism:

$$
\mathrm{CuFeS}_{2}+2 \mathrm{O}_{2}+\mathrm{Fe}_{2}\left(\mathrm{SO}_{4}\right)_{3} \rightarrow \mathrm{CuSO}_{4}+3 \mathrm{FeSO}_{4}+\mathrm{S}^{\mathrm{o}}
$$


This, apart from dissolution of the metal ions, produces ferrous iron and elemental sulfur $\left(\mathrm{S}^{\circ}\right)$. It is this ferrous iron and the elemental sulfur that form the substrate for microbial growth according to reaction:

$$
2 \mathrm{FeSO}_{4}+1 / 2 \mathrm{O}_{2}+\mathrm{H}_{2} \mathrm{SO}_{4} \stackrel{\text { Ac.Tf }}{\rightarrow} \mathrm{Fe}_{2}\left(\mathrm{SO}_{4}\right)_{3}+\mathrm{H}_{2} \mathrm{O}
$$

and:

$$
\mathrm{S}^{\mathrm{o}}+2 \mathrm{O}_{2}+2 \mathrm{H}^{+} \stackrel{\text { Ac.Tf }}{\rightarrow} \mathrm{H}_{2} \mathrm{SO}_{4}
$$

The ferric iron thus formed is hydrolyzed in aqueous solution if $\mathrm{pH}$ is higher.

$$
\begin{gathered}
\mathrm{Fe}^{3+}+\mathrm{H}_{2} \mathrm{O} \Leftrightarrow \mathrm{FeOH}^{2+}+\mathrm{H}^{+} \\
\mathrm{Fe}^{3+}+2 \mathrm{H}_{2} \mathrm{O} \Leftrightarrow \mathrm{Fe}(\mathrm{OH})_{2}^{+}+2 \mathrm{H}^{+}
\end{gathered}
$$

Reaction (5) increases the $\mathrm{pH}$, but the reaction (7) and (8) reduce and stabilizes it. So the extent of ferric iron hydrolysis is dependent on $\mathrm{pH}$.

In India, the demand for copper is also increasing with industrialisation and to meet the requirement of the metal, the low grade ores/tailings located in Malanjkhand (M.P.), Khetri (Rajasthan) and Singhbhum (Jharkhand) regions can be an important source. The Malanjkhand Copper Project (MCP) is the largest open-cast mine having copper deposits of 22 million $\mathrm{T}$ of low grade ores $(\sim 0.3 \%)$ remaining untapped because no conventional processing technology has been found suitable. Biohydrometallurgical processing can be explored to assess the technical feasibility and it has so been projected to recover copper from this low grade reserve [12-14]. The R \& D studies carried out on bench scale for bio-leaching of copper from the lean MCP ore at NML, Jamshedpur are presented in this paper with the aim of optimizing the process parameters using enriched culture of $A$. ferrooxidans, initially derived from mine water of MCP and also with the adapted isolates to compare their efficiency.

\section{Materials and Methods}

\subsection{Copper Ore}

Lean grade copper ore $(\sim 0.3 \% \mathrm{Cu})$ obtained as lumps from the mines of Malanjkhand Copper Project, M.P was crushed, ground and sieved to obtain different size fractions. Representative samples were then prepared by coning and quartering method for ore and each fraction to get sieve analysis and respective chemical analysis by using atomic absorption spectrophotometer [15]. Chemical analysis of the ore is given in Table $\mathbf{1}$ whereas chemical analysis of sieve fractions is given in Table 2 . It may be seen that the composition of the different fractions are almost same.

\subsection{Phases in the Copper Ore}

The low grade Malanjkhand copper ore is mostly a granitic
Table 1. Chemical analysis of copper ore from MCP (\%).

\begin{tabular}{cccccccc}
\hline $\mathrm{Cu}$ & $\mathrm{Ni}$ & $\mathrm{Fe}$ & $\mathrm{Co}$ & $\mathrm{Zn}$ & $\mathrm{S}$ & $\mathrm{TiO}_{2}$ & $\mathrm{SiO}_{2}$ \\
\hline 0.32 & 0.23 & 3.91 & 0.05 & 0.05 & 2.8 & 0.60 & 68.2 \\
\hline
\end{tabular}

Table 2. Chemical analysis of different sieve fractions of copper ore.

\begin{tabular}{cccccc}
\hline \multirow{2}{*}{$\begin{array}{c}\text { Particle } \\
\text { size }(\mu \mathrm{m})\end{array}$} & \multirow{2}{*}{$\begin{array}{c}\text { Fraction } \\
\text { retained (\%) }\end{array}$} & $\begin{array}{c}\text { Cumulative } \\
\text { Fraction }\end{array}$ & \multicolumn{3}{c}{ Composition (\%) } \\
\cline { 5 - 7 } & & retained (\%) & $\mathrm{Cu}$ & $\mathrm{Ni}$ & $\mathrm{Fe}$ \\
\hline $150-76$ & 3.33 & 3.33 & 0.321 & 0.228 & 3.90 \\
$76-50$ & 34.92 & 38.25 & 0.316 & 0.225 & 3.92 \\
$<50$ & 61.75 & 100 & 0.320 & 0.230 & 3.91 \\
\hline
\end{tabular}

rock and the preliminary mineralogical studies indicated the presence of chalcopyrite in the cracks and fissures of quartz veins. The petrological analysis for distribution of phases (Figure 1) showed the presence of chalcopyrite in the form of irregular grains, and pyrite (brighter than chalcopyrite) was observed within feldspar grains. The bulk ore was slightly pink in appearance due to high percentage of granite in the ore body.

XRD phase identification analysis of the ore (Table 3) showed quartz $\left(\mathrm{SiO}_{2}\right)$, chalcopyrite $\left(\mathrm{CuFeS}_{2}\right)$, pyrite $\left(\mathrm{FeS}_{2}\right)$ as the major phases whereas bornite was the minor phase.

\subsection{Bacteria Used and Bioleaching Experiments}

The micro-organism used in this study was a culture of Acidithiobacillus ferrooxidans (A. ferrooxidans), derived by successive enrichment of mine water of MCP using ferrous sulfate as the substrate in $9 \mathrm{~K}$ nutrient media at $\mathrm{pH}$ 2.0. The isolated microbial culture from the mine water was grown and specific colonies were successively re-plated and sub-cultured to get the enriched culture containing $A$. ferrooxidans. The bacterium was identified for its shape and size by staining as straight rods with variable motility and examining the cell count microscopically. The enriched culture thus derived was used in subsequent bioleaching experiments $[14,16]$. In general, bioleaching tests were carried out in $500 \mathrm{~mL}$ conical flasks with $200 \mathrm{~mL}$ of total solution. Experiments were carried out using unadapted culture and culture adapted over the ore. Leaching solution was inoculated with $10 \%$ ( $/ \mathrm{v})$ of active and enriched culture and a known quantity of sized ore was added. In case of sterile/control experimental sets, mercuric chloride $(0.02 \mathrm{~g} / \mathrm{L})$ was added as a bactericide. For the experiments with adapted isolates, the enriched culture was initially adapted over ore of $<150 \mu \mathrm{m}$ size at $5 \%(\mathrm{w} / \mathrm{v})$ pulp density, $\mathrm{pH} 2.0$ and $35^{\circ} \mathrm{C}$, and the culture was further grown in large volumes for the use in further experiments. 


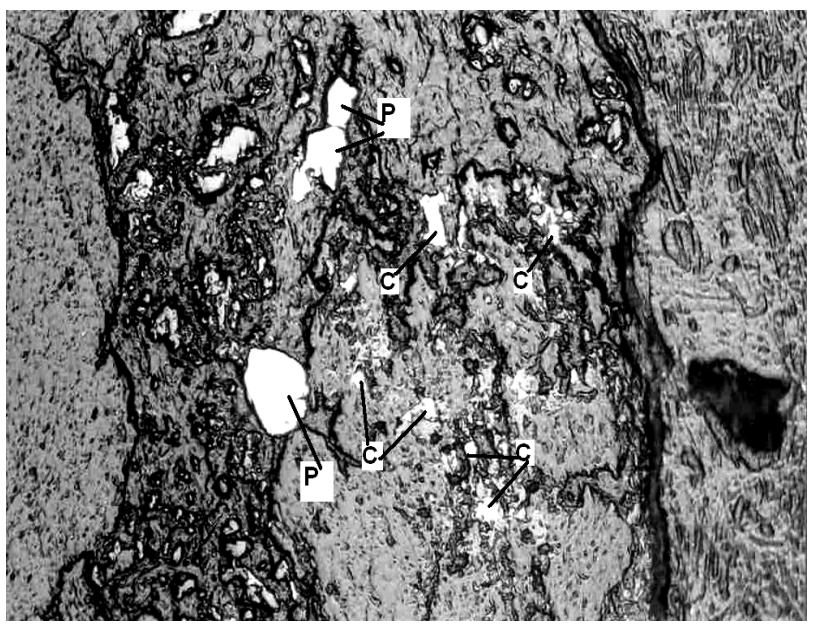

Figure 1. Petrological micrograph of copper ore (at 100×) [C-chalcopyrite, P-pyrite].

Table 3. XRD Phase analysis of copper ore.

\begin{tabular}{|c|c|c|}
\hline \multirow{2}{*}{ Sample } & \multicolumn{2}{|c|}{ Phases } \\
\hline & Major Phases & Minor Phases \\
\hline Ore & Chalcopyrite, Pyrite, Silica & Bornite \\
\hline
\end{tabular}

Flasks containing ore slurry were incubated at a temperature of $35^{\circ} \mathrm{C} \pm 0.2^{\circ} \mathrm{C}$ and $\mathrm{pH} 2.0$ in incubator shaker with orbital motion at $120 \mathrm{rpm}$ unless otherwise stated. During experiments, samples were mostly taken at 5 days intervals for chemical analysis and $\mathrm{pH}$ of the leach solution was maintained on alternate days (initial $\mathrm{pH}$ maintained with $10 \mathrm{~N}_{2} \mathrm{SO}_{4}$ ). Redox potential ( $\mathrm{E}_{\mathrm{SCE}}$ ) was also measured against saturated calomel electrode and reported as such in the text. A $0.5 \mathrm{~mL}$ supernatant solution was withdrawn for analysis of metals by AAS (Model: GBC980BT). The iron(II) concentration was determined by titrating against $0.05 \mathrm{~N}$ potassium dichromate solution. All the inoculated sets had their corresponding sterile sets prepared under the same conditions. Upon termination of the leaching experiments, the solid residues were dried and samples were taken for chemical analysis and XRD phase identification. Cell count was done using Petroff Hauser's Counting Chamber and enumerated using biological microscope. The bioleaching experiments were mostly repeated for 3 times and the copper recoveries were found to vary within \pm 0.5 to $1.0 \%$.

\section{Results and Discussion}

In the present work, extensive bench scale studies on bioleaching of copper from lean grade copper ore of Malanjkhand Copper Project (MCP) are reported for optimisation of the critical parameters. The details are presented and discussed below.

\subsection{Bioleaching Experiments Using Unadapted Culture}

Acidithiobacillus ferrooxidans isolated from the mine water and sub-cultured in presence of ferrous sulfate was used in the form of enriched culture in bio-leaching experiments.

\subsubsection{Effect of $\mathrm{pH}$}

Bioleaching of copper ore was carried out using enriched culture at $\mathrm{pH}$ ranging from $1.5-2.5$ at a pulp density of $5 \%(\mathrm{w} / \mathrm{v})$ and $25^{\circ} \mathrm{C}$. Figure 2 shows the maximum (40\%) bio-recovery of copper at $\mathrm{pH} 2.0$ in 35 days which was mainly governed by increase in bacterial oxidation under this condition. Further increase in time had no effect on recovery of copper. During this period, low copper recovery of $17 \%$ was, however, observed at $\mathrm{pH} 2.0$ in control/sterile leaching experiment. This may be correlated with high bio-dissolution of iron (45\%) at $\mathrm{pH} 2.0$ in comparison to $21 \%$ recovery in control leaching (Figure 3). Figure 3 also describes the trend of $\mathrm{Fe}(\mathrm{III})$ concentration

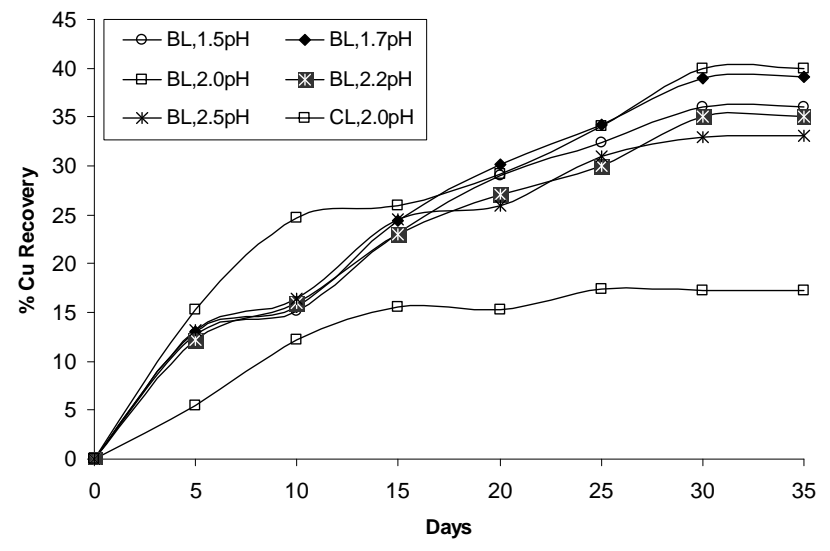

Figure 2. Recovery of copper at varying pH using unadapted culture [T: $25^{\circ} \mathrm{C}$, pulp density:5\% (w/v), particle size: $<50 \mu \mathrm{m}]$.

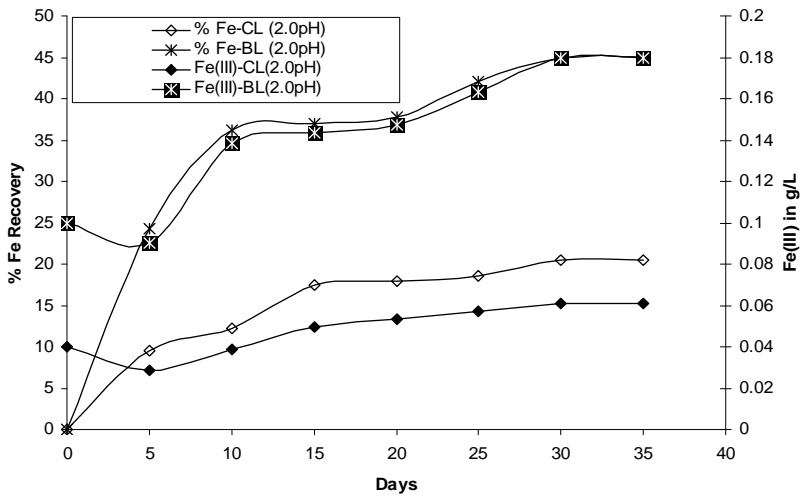

Figure 3. Iron recovery (\%) with variation in $\mathrm{Fe}(\mathrm{III})$ ion concentration $(\mathrm{g} / \mathrm{L})$ using unadapted culture at $35^{\circ} \mathrm{C},<50$ $\mu \mathrm{m}$ particles and pH 2.0. [BL-Bio-leaching, CL-Chemical Leaching]. 
encountered during the bio-leaching/control experiments. It may be mentioned that iron dissolved in the form of ferrous ion from the pyrite/chalcopyrite present in the ore would be converted to ferric ions during bio-leaching with the help of $A$. ferrooxidans. The iron(III) present in the solution has thus improved the copper bio-dissolution process from $5^{\text {th }}$ day onwards (Figure 2) through indirect mechanism. With a rise in $\mathrm{pH}$ to 2.5 , the biorecovery of copper decreased to $32 \%$ due to hydronium jarosite precipitation on the surface of the ore particles which was identified by XRD phase analysis (Table 3) of leach residue [17]. Acid requirement was also an important aspect to be taken in to consideration which was at a minimum level $\left(1.25 \mathrm{~mL}\right.$ of $10 \mathrm{~N} \mathrm{H}_{2} \mathrm{SO}_{4}$ for $200 \mathrm{~mL}$ solution) at $\mathrm{pH} 2.0$ due to higher bacterial activity; whereas it was $75 \%$ higher acid that was consumed in control experiments at the same $\mathrm{pH}$.

\subsubsection{Effect of Pulp Density (PD)}

Bio-dissolution of copper was investigated by varying pulp density in the range $5 \%-20 \%(\mathrm{w} / \mathrm{v})$ at $\mathrm{pH} 2.0$ and $35^{\circ} \mathrm{C}$ with $<50 \mu \mathrm{m}$ size particles inoculating $10 \%(\mathrm{v} / \mathrm{v})$ enriched culture/isolate from $\mathrm{Cu}$-mine water without adaptation in $200 \mathrm{~mL}$ leaching medium while shaking at 100 rpm. From the results shown in Figure 4, it was clear that bio-recovery of copper was much high (72\%) at lower pulp density of $5 \%(\mathrm{w} / \mathrm{v})$ in 35 days as compared to $32 \% \mathrm{Cu}$ dissolved in chemical leaching. The bio-dissolution of copper decreased with increase in pulp density. This may be attributed to the deficiency of oxygen availability and increased concentration of metal ions causing toxicity to bacterial growth at higher pulp densities. At 5\% (w/v) $\mathrm{PD}$, redox potential increased from $522 \mathrm{mV}$ in 5 days to $661 \mathrm{mV}$ in 35 days for bioleaching whereas the corresponding $\mathrm{E}_{\mathrm{SCE}}$ were $312 \mathrm{mV}$ and $401 \mathrm{mV}$ in control leaching at this pulp density. These data signified that high metal dissolution was governed by high redox potential owing to the high ferric iron concentration in the solution. These studies further showed increase in copper recovery with an increase in temperature from $25^{\circ} \mathrm{C}$ (Figure 2) to $35^{\circ} \mathrm{C}$ under similar conditions. This may be attributed to improved biochemical action of bacteria-A. ferrooxidans at $35^{\circ} \mathrm{C}$.

\subsubsection{Effect of Particle Size}

Studies on effect of particle sizes on bio-leaching of copper are shown in Figure 5. It may be seen that increasing fineness from $150-76 \mu \mathrm{m}$ to $<50 \mu \mathrm{m}$ increased the metal recovery from $39 \%$ to $72 \%$ in 35 days at $5 \%$ $(\mathrm{w} / \mathrm{v}) \mathrm{PD}, \mathrm{pH} 2.0$ and $35^{\circ} \mathrm{C}$. This could be mainly due to the availability of increased surface area of the ore leading to better permeation of leachant to oxidize the copper sulfide present in the ore. Finer particles were increaseingly exposed to lixiviant that dissolved copper from the chalcopyrite phase.

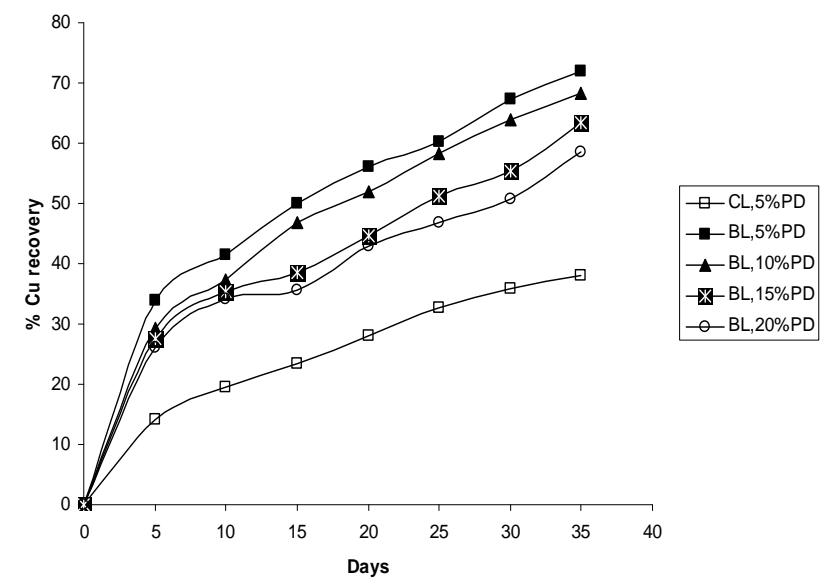

Figure 4. Copper recovery at different pulp densities using unadapted culture at $35^{\circ} \mathrm{C},<50 \mu \mathrm{m}$ particles, $\mathrm{pH} 2.0$. [BL-Bio-leaching, CL-Chemical Leaching].

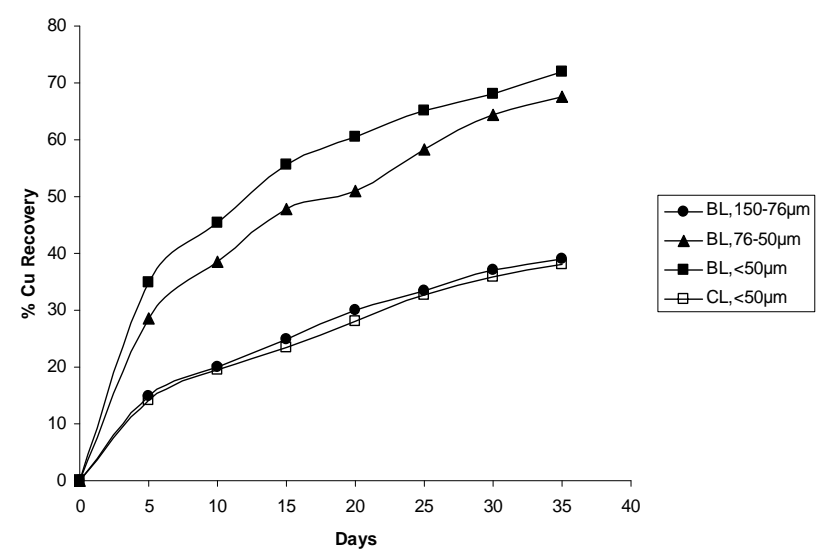

Figure 5. Effect of particle size on bioleaching of copper ore with unadapted bacteria [T:35 ${ }^{\circ} \mathrm{C}, \mathrm{pH} 2.0,5 \%$ (w/v) PD; BL: Bio-leaching].

\subsubsection{Effect of Temperature}

In general, chemical reaction rate increases with rise in temperature, but the bacterial culture containing A. ferrooxidans being mesophilic in nature, the experiments were conducted only up to $35^{\circ} \mathrm{C}$ to ensure sustenance of the bacteria. Effect of temperature on bioleaching at $5 \%$ $\mathrm{PD}$ using $10 \%(\mathrm{v} / \mathrm{v})$ enriched culture at $\mathrm{pH} 2.0$ with $<50$ $\mu \mathrm{m}$ size particles is depicted in Figure 6. Maximum copper recovery was found to be $72 \%$ at $35^{\circ} \mathrm{C}$ in 35 days as against $44 \%$ at $25^{\circ} \mathrm{C}$, whereas recovery under control leaching was found to be only $32 \%$ at $35^{\circ} \mathrm{C}$ (Figure 2). Higher bio-dissolution of the metal may be correlated with higher $\mathrm{E}_{\mathrm{SCE}}$ that was attained from 316 to $661 \mathrm{mV}$ in 35 days in bio-leaching as compared to that of control leaching which varied from 312 to $401 \mathrm{mV}$ during the corresponding period. The bacterial population in bio-leaching at $35^{\circ} \mathrm{C}$ increased from $6 \times 10^{7}$ to $9.8 \times 10^{8}$ cells $/ \mathrm{mL}$ in 35 days showing strong oxidizing conditions for improved metal recovery. 


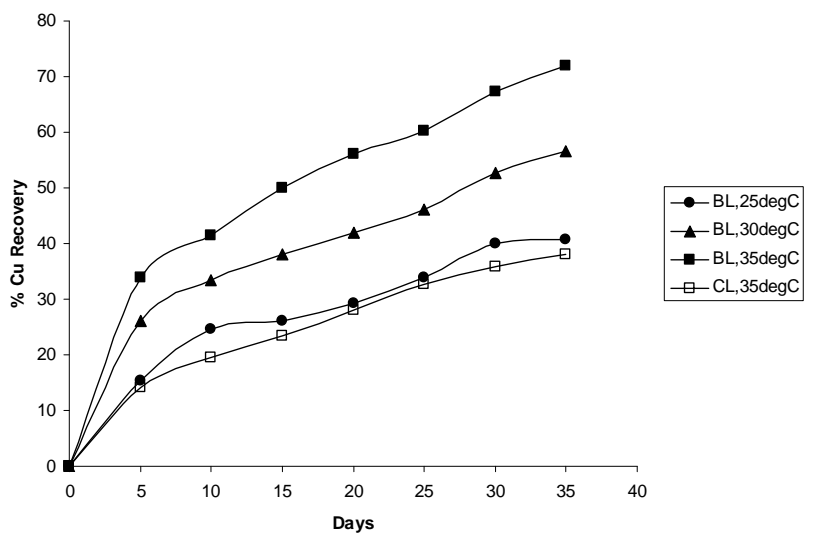

Figure 6. Effect of temperature on bioleaching of copper ore with unadapted culture [PD 5\% (w/v), pH 2.0, <50 $\mathrm{\mu m}$ particles; BL: Bio-leaching, CL: Chemical Leaching].

\subsection{Bioleaching Experiments Using Adapted Culture}

As described earlier, the bacteria isolated from mine water was adapted on $5 \%(\mathrm{w} / \mathrm{v})$ ore at $\mathrm{pH} 2.0$ and $35^{\circ} \mathrm{C}$ and the adapted enriched culture after further sub-culturing was used in bio-leaching.

\subsubsection{Effect of $\mathrm{pH}$}

Bioleaching of copper from the ore was carried out using adapted culture of isolate at varying $\mathrm{pH}$ from $1.5-2.5$ at a pulp density of $5 \%(\mathrm{w} / \mathrm{v})$ and $25^{\circ} \mathrm{C}$ and results are depicted in Figure 7. The bio-recovery was found to be maximum (41\%) in 35 days at $\mathrm{pH} 1.7$ and 2.0, although initial rate of copper biodissolution was faster at $\mathrm{pH}$ 1.7. Acid consumption was slightly more at $\mathrm{pH} 1.7(1.8 \mathrm{~mL}$ $\left.10 \mathrm{~N} \mathrm{H}_{2} \mathrm{SO}_{4}\right)$ as compared to that of $\mathrm{pH} 2.0(0.5 \mathrm{~mL} 10 \mathrm{~N}$ $\mathrm{H}_{2} \mathrm{SO}_{4}$ ). This indicated that bio-chemical oxidation at these $\mathrm{pH}$ values was pronounced and the lower $\mathrm{pH}$ of 1.5 was not that effective for bio-oxidation with $36 \% \mathrm{Cu}$ recovery. High recovery at $\mathrm{pH} 2.0$ with the adapted culture was mainly governed by increase in bacterial oxidation which was demonstrated by high $\mathrm{Fe}(\mathrm{III})$ concentration of $0.26 \mathrm{~g} / \mathrm{L}$ in 35 days as compared to $0.18 \mathrm{~g} / \mathrm{L}$ iron(III) in case of un-adapted culture (Figure 3). With a rise in $\mathrm{pH}$ above 2.0 , the recovery of copper decreased due to the jarosite formation on the ore surface. A recovery of $17 \%$ copper was attained in control experiments at $\mathrm{pH} 2.0$ during the same period.

\subsubsection{Effect of Particle Size}

Effect of particle size on bio-leaching of copper was investigated for the three size range at 5\% (w/v) PD using $10 \%(\mathrm{v} / \mathrm{v})$ enriched culture of adapted bacteria in $200 \mathrm{~mL}$ leaching medium at $\mathrm{pH} 2.0$ and $25^{\circ} \mathrm{C}$. As shown in Figure 8, maximum copper recovery $(47.5 \%)$ was obtained with $<50 \mu \mathrm{m}$ size material using adapted culture which was higher than that of the recovery of $40 \%$ with non-adapted

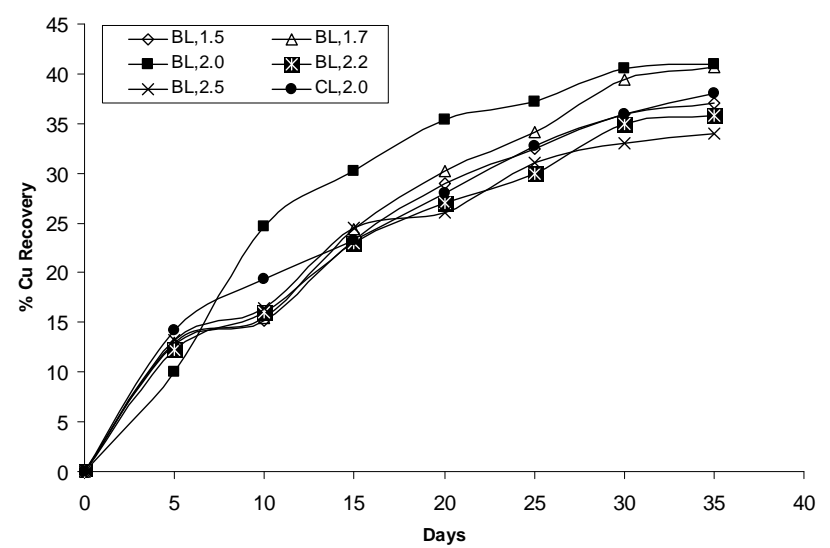

Figure 7. Recovery of copper during bioleaching with adapted culture at different pH [PD: $5 \%(w / v), T: 25^{\circ} \mathrm{C}$, particle size: $<50 \mu \mathrm{m}]$.

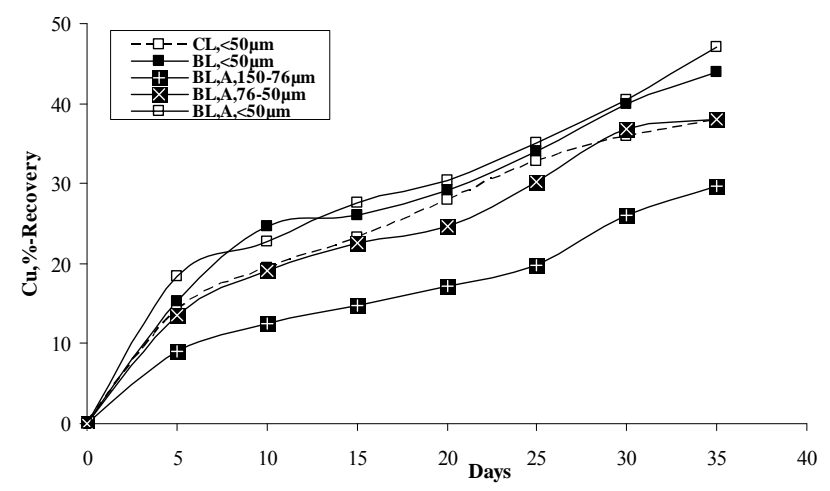

Figure 8. Cu recovery during bioleaching with adapted culture at different particle size of ore [pH: 2.0, PD: 5\% (w/v), Temp: $25^{\circ} \mathrm{C}$, BL-A: Bioleaching with adapted culture, BL: Bioleaching without adapted culture].

culture (Figure 2). This may be attributed to the fact that metal ion tolerance of adapted strains contributed more to the bioleaching of metal in comparison to the unadapted culture. Copper bio-recovery of $29.68 \%$ and $38.31 \%$ were obtained with $150-76 \mu \mathrm{m}$ and $76-50 \mu \mathrm{m}$ size ore particles respectively in 35 days. In control experiment for $<50 \mu \mathrm{m}$ size ore, recovery of copper was $32 \%$ in 35 days. Maximum rise in $\mathrm{E}_{\mathrm{SCE}}$ of $654 \mathrm{mV}$ was noticed for the bioleaching with adapted bacteria in 35 days with $<50 \mu \mathrm{m}$ size particles which resulted in high metal dissolution, because of favoured biochemical oxidation of the finer size particles.

\subsubsection{Effect of Pulp Density}

Recovery of copper at different pulp density at $25^{\circ} \mathrm{C}$ temperature, $\mathrm{pH} 2.0$ and $<50 \mu \mathrm{m}$ size particles along with the change in $\mathrm{E}_{\mathrm{SCE}}(\mathrm{mV})$ values in 35 days has been presented in Figures 9-10. The control experiments were also run under similar conditions at $5 \%(\mathrm{w} / \mathrm{v})$ PD. The maximum copper recovery was found to be $47.5 \%$ and $44 \%$ with adapted and un-adapted culture as mentioned 


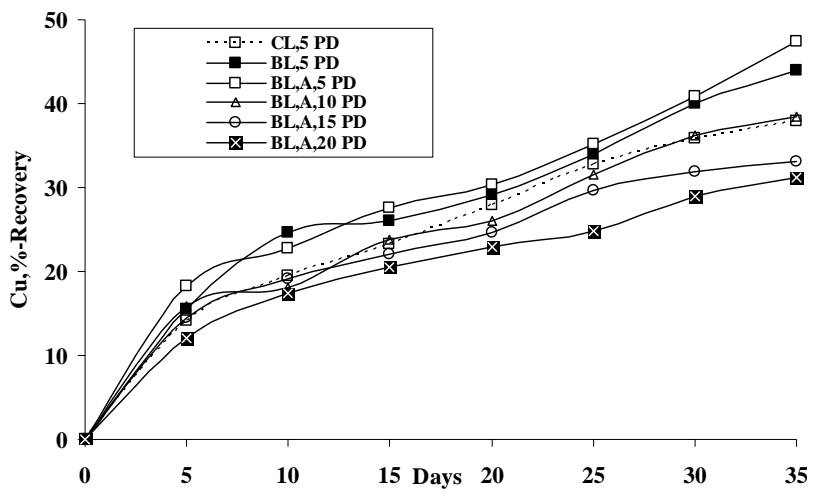

Figure 9. Effect of pulp density on bioleaching of copper with adapted culture [T: $25^{\circ} \mathrm{C}$, particle size $<50 \mu \mathrm{m}, \mathrm{pH}$ : 2.0].

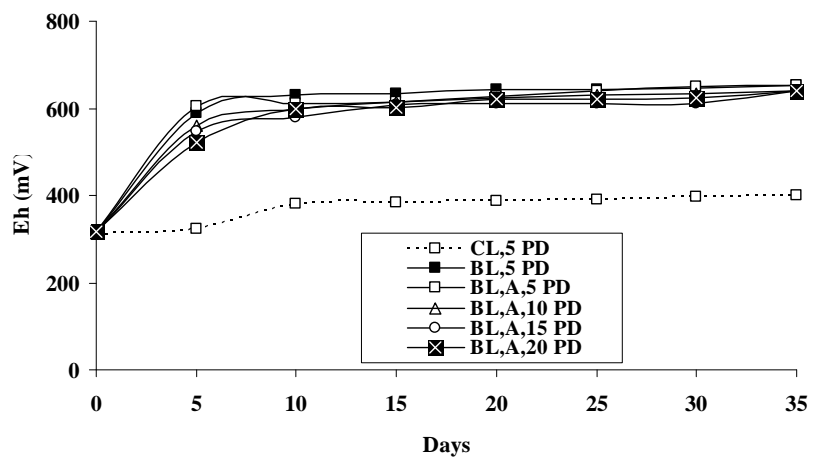

Figure 10. Change in redox potential during bioleaching at different pulp densities [T: $25^{\circ} \mathrm{C}$, particle size: $<50 \mu \mathrm{m}, \mathrm{pH}$ : 2.0].

earlier, whereas $32 \%$ copper was leached out in sterile/control experiments at 5\% (w/v) PD in 35 days. Copper bio-recovery of $38.5 \%, 33.04 \%$ and $31.19 \%$ was obtained with the adapted culture at 10, 15 and $20 \%$ PD respectively (Figure 9); this indicated decreased metal recovery at higher pulp densities. At $5 \%(\mathrm{w} / \mathrm{v})$ pulp density, maximum redox potential of the solution was found to be $390 \mathrm{mV}$ for the chemical leaching, whereas it was 652 and $654 \mathrm{mV}$ in 35 days for leaching with nonadapted and adapted cultures respectively (Figure 10). The higher redox potential may be correlated with the high copper recovery with adapted culture at this pulp density.

\subsubsection{Effect of Temperature}

Effect of temperature on bio-dissolution of copper using the enriched culture was investigated in the range $25^{\circ} \mathrm{C}$ $35^{\circ} \mathrm{C}$ at $5 \%(\mathrm{w} / \mathrm{v}) \mathrm{PD}$ and $\mathrm{pH} 2.0$ and results are reported in Figure 11. Copper bio-recovery was maximum (75.3\%) with the adapted culture in leaching as compared to the recovery $(72 \%)$ with non-adapted bacteria, which may also be attributed to the metal ion tolerance of the adapted strains. It may be mentioned that strains can tolerate only up

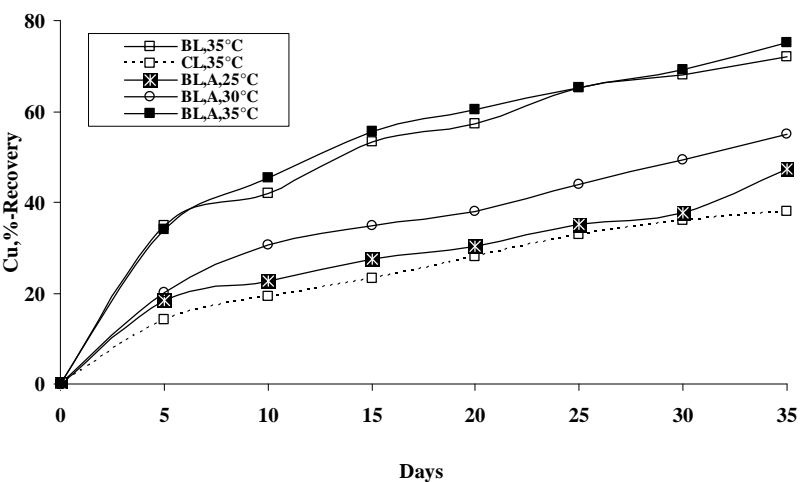

Figure 11. Effect of temperature on copper bio-recovery with adapted culture [Particle size: $<50 \mu \mathrm{m}, \mathrm{pH}$ 2.0, PD: $5 \%(w / v)]$.

to a certain critical concentration of metal ions under normal conditions, generally $\approx 1 \mathrm{~g} / \mathrm{L}$ for $\mathrm{Cu}$, which on adaptation rises to $55 \mathrm{~g} / \mathrm{L}[5,18]$. It is the tolerance limit of $A$. ferrooxidans which is enhanced through adaptation leading to the increased metal dissolution. Bio-recovery of copper increased from $47.5 \%-75.3 \%$ with increase in temperature from $25^{\circ} \mathrm{C}$ to $35^{\circ} \mathrm{C}$. At $35^{\circ} \mathrm{C}$ temperature, the redox potential varied between 316 to $661 \mathrm{mV}$ and 318 to $668 \mathrm{mV}$ in bio-leaching experiments with unadapted and adapted cultures whereas it varied between 312 to $401 \mathrm{mV}$ in control/chemical leaching in 35 days. During bioleaching, increase in bacterial growth was observed from $6 \times 10^{7}$ to $9.8 \times 10^{8}$ and $9.6 \times 10^{7}$ to $11.3 \times 10^{8}$ cells $/ \mathrm{mL}$ with unadapted and adapted bacterial culture respectively. It was interesting to see that the bacterial population increased with time resulting in improved metal bio-recovery. Apparently the higher cell population in case of leaching with adapted culture resulted in better metal dissolution. A slightly higher redox potential (668 $\mathrm{mV})$ and cell counts $\left(11.3 \times 10^{8}\right)$ favoured improved metal dissolution $(75.3 \%)$ in case of adapted isolates as a consequence of metal tolerance of bacteria on ore [18].

\subsection{XRD Phase Analysis of Leach Residue}

The XRD phase analysis of the residue (Table 3) obtained during bio-leaching at $35^{\circ} \mathrm{C}$ and $\mathrm{pH} 2.5$ with the adapted culture showed that hydronium jarosite

$\left[\mathrm{H}_{3} \mathrm{OFe}_{3}\left(\mathrm{SO}_{4}\right)_{2}(\mathrm{OH})_{6}\right]$ and silica were present as major phases and chalcopyrite and pyrite as the minor phases. Chalcopyrite and pyrite were found as major phases in the ore.

During the bioleaching, jarosite was formed as,

$$
\begin{aligned}
& 3 \mathrm{Fe}^{3+}+2 \mathrm{SO}_{4}{ }^{2-}+\mathrm{X}^{+}+6 \mathrm{H}_{2} \mathrm{O} \\
& \Leftrightarrow \mathrm{X}\left[\mathrm{Fe}_{3}\left(\mathrm{SO}_{4}\right)_{2}(\mathrm{OH})_{6}\right]+6 \mathrm{H}^{+}
\end{aligned}
$$

Precipitation of jarosite was lower at $\mathrm{pH} 2$; but at $\mathrm{pH}$ 2.5, its precipitation increased resulting in lower biorecovery. 


\section{Conclusions}

Bioleaching of copper from the low grade chalcopyrite ore of MCP, India by enriched culture containing Acidithiobacillus ferrooxidans (A. ferrooxidans) is effective for extraction of the metal.

1) The maximum bioleaching of copper was $75.3 \%$ and $72 \%$ with the enriched culture adapted on the ore and with the native culture without adaptation respectively.

2) The optimum condition is worked out to be: $\mathrm{pH} 2.0$, $35^{\circ} \mathrm{C}$ temperature and $5 \%(\mathrm{w} / \mathrm{v})$ pulp density for the bioleaching process to leach maximum copper metal (75.33\%) from the ore of $<50 \mu \mathrm{m}$ size particles in 35 days.

3) Additionally, the enriched culture containing A. ferrooxidans possesses the capacity to generate sulfuric acid through sulfur oxidation to maintain the $\mathrm{pH}$ in leaching solution and allow further copper dissolution through the action of $\mathrm{Fe}(\mathrm{III})$ ions.

4) The higher copper recovery with the enriched adapted culture may be correlated with the presence of higher iron level in solution and high redox potential $(668 \mathrm{mV})$ acquired under the optimum conditions as compared to un-adapted culture.

\section{Acknowledgements}

The authors are thankful to the Director, NML Jamshedpur for giving permission to publish the paper. Thanks are also due to the Malanjkhand Copper Project (Hindustan Copper Limited) for providing the ore sample and to Dr. A. K. Upadhyay of Analytical Chemistry Centre, CSIR-NML, Jamshedpur for chemical analysis.

\section{REFERENCES}

[1] A. E. Troma, "New Trends in Biohydrometallurgy," In: R. W. Smith and M. Misra, Eds., Mineral Bioprocesing, The Minerals, Metals \& Materials Society, Pennsylvania, 1991, p. 43.

[2] A. R. Colmer and M. E. Hinkle, "The Role of Microorganisms in Acid Mine Drainage," Science, Vol. 106, No. 2751, 1947, pp. 253-256. doi:10.1126/science.106.2751.253

[3] G. Rossi, "Biohydrometallurgy," McGraw-Hill Book Company, Hamburg, 1990.

[4] K. A. Natarajan, "Electrochemical Aspects of Bioleaching of Base-Metal Sulphides," In: H. L. Ehrlich and C. L. Brierley, Eds., Microbial Mineral Recovery, McGrawHill Book Company, New York, 1990, p. 79.

[5] A. Das, J. M. Modak and K. A. Natarajan, "Studies on Multi-Metal Ion Tolerance of Thiobacillus Ferrooxidans," Minerals Engineering, Vol. 10, No. 7, 1997, pp. 743-749. doi:10.1016/S0892-6875(97)00052-6

[6] M. P. Silverman, "Mechanism of Bacterial Pyrite Oxidation," Journal of Bacteriology, Vol. 94, 1967, pp. 1046-
1051.

[7] L. A. Brickett, R. W. Hammack and H. M. Edenborn, "Comparison of Methods Used to Inhibit Bacterial Activity in Sulfide Ore Bioleaching Studies," Hydrometallurgy, Vol. 39, No. 1-3, 1995, pp. 293-305. doi:10.1016/0304-386X(95)00043-G

[8] A. Schippers and W. Sand, "Bacterial Leaching of Metal Sulfides Proceeds by Two Indirect Mechanisms via Thiosulfate or via Polysulfides and Sulfur," Applied and Environmental Microbiology, Vol. 65, No. 1, 1999, pp. 319 321.

[9] L. Patnaik, R. N. Kar and L. B. Sukla, "Infuluence of pH on Bioleaching of Copper and Zinc from Complex Sulphide Concentrate Using Thiobacillus Ferrooxidans," Transactions of the Indian Institute of Metals, Vol. 54, No. 4, 2001, pp. 139-144.

[10] G. S. Hansford and T. Vargas, "Chemical and Electrochemical Basis of Bioleaching Processes," Hydrometallurgy, Vol. 59, No. 2-3, 2001, pp. 135-145. doi:10.1016/S0304-386X(00)00166-3

[11] W. Sand, T. J. Gehrke and A. Schippers, "(Bio)Chemistry of Bacterial Leaching - Direct vs. Indirect Bioleaching," Hydrometallurgy, Vol. 59, No. 2-3, 2001, pp. 159-175. doi:10.1016/S0304-386X(00)00180-8

[12] A. D. Agate, K. M. Paknikar and N. J. Khinvasara, "Scale-Up Leaching of Malanjkhand Copper Ores-A Case Study," In: J. Salley, R. G. L. Mcready and P. L. Wichlaez, Eds., Biohydrometallurgy, CANMET, 1989, p. 577.

[13] D. Pradhan, S. Pal, L. B. Sukla, G. Roy Choudhary and T. Das, "Bioleaching of Low Grade Copper Ore Using Indigenous Microorganism," Indian Journal of Chemical Technology, Vol. 15, 2008, pp. 558-592.

[14] S. C. Pal, K. D. Mehta, B. D. Pandey and T. R. Mankhand, "Biomineral Processing for Extraction of Copper Metal from Lean Ore of Malanjkhand Copper Project," International Conference on Emerging Trends in Mineral Processing and Extractive Metallurgy (ICME-2005), Bhubaneswar, India, pp. 246-255.

[15] F. Habashi, "Chalcopyrite: Its Chemistry and Metallurgy," McGraw-Hill, New York, 1978.

[16] D. Bevilaqua, A. L. L. C. Leite, O. Garcia Jr. and O. H. Tuovinen, "Oxidation of Chalcopyrite by Acidithiobacillus ferrooxidans and Acidithiobacillus thiooxidans in Shake Flasks," Process Biochemistry, Vol. 38, No. 4, 2002, pp. 587-592. doi:10.1016/S0032-9592(02)00169-3

[17] M. B. Stott, H. R. Watling, P. D. Franzmann and D. Sutton, "The Role of Iron-Hydroxy Precipitates in the Passivation of Chalcopyrite during Bioleaching," Minerals Engineering, Vol. 13, No. 10, 2000, pp. 1117-1127. doi:10.1016/S0892-6875(00)00095-9

[18] Y. Rodriguez, A. Ballester, M. L. Blazquez, F. Gonzalez and J. A. Muňoz, "New Information on the Chalcopyrite Bioleaching Mechanism at Low and High Temperature," Hydrometallurgy, Vol. 71, No. 1-2, 2003, pp. 47-56. doi:10.1016/S0304-386X(03)00173-7 